\title{
Editorial
}

\section{Should trees have standing: 40 years on?}

When Professor Philippe Sands suggested over lunch at the formal public launch conference for the Journal of Human Rights and the Environment and the Global Network for the Study of Human Rights and the Environment (GNHRE) in Bristol, in June 2010, that we should dedicate a special edition of the journal to Stone's iconic 1972 article, 'Should Trees Have Standing?', the idea immediately struck an exciting chord. The contributions in this special edition more than amply fulfil the rich promise of that initial suggestion. Each of the contributors has generously provided a philosophically rich and thoughtful engagement with Stone's iconic work, and he, in turn, has provided a typically intellectually engaged - and engaging - response.

Editing this special edition has been a particular joy - not only because of the outstanding quality of the thought contained in the contributions - but because the edition itself represents a particularly exciting moment in the journal's own contribution to the important project of exploring how we twenty-first-century humans can interrogate, re-imagine and re-constitute our relationships with the complex, multiple, dynamic ecologies of which we are but a part. Nothing could be more urgent than the quest for 'worlds other' than the unsustainable status quo. Philosophical and jurisprudential engagement with questions of legal standing, of legal subjectivity and personhood, of legal 'rights-bearers', form an important part of the urgent search for an eco-humane future worthy of the name, for we live in a world pervasively structured by law's power to foreclose - or open - the 'categories of the possible' a world in which law's intervention always has inescapably material effect.

The rich contributions to this edition represent a fabulous meditation upon one of the most refreshing juridical re-imaginations of possible 'worlds other' to have emerged from legal scholarship in the past 40 years.

\section{ACKNOWLEDGEMENTS}

The publisher and editor gratefully acknowledge permission to reprint Christopher D Stone's 1972 article in full:

Christopher D Stone, 'Should Trees Have Standing? - Toward Legal Rights for Natural Objects' (1972) 45 Southern Californa Law Review 450-501 reprinted with the permission of the Southern California Law Review.

Anna Grear (Co-Editor in Chief) Associate Professor of Law, University of Waikato, New Zealand and Director, Global Network for the Study of Human Rights and the Environment (GNHRE) 